\title{
JOHN BURIDAN AND NICHOLAS OF AUTRECOURT ON CAUSALITY AND INDUCTION
}

\author{
BY J. M. M. H. THIJSSEN*
}

The names of John Buridan (1300-after 1358) and Nicholas of Autrecourt (1300-after 1350) are often associated with the so-called Ockhamist statute of 1340 at the University of Paris. For a long time the discussion centered upon the question: Was this statute directed against Ockham or Autrecourt? Puzzling also was the part Buridan played, who presumably was rector at the time that the statute was promulgated. Should he, as an alleged 'Ockhamist,' be accused of patricide or did he defend Ockham against the attacks of Autrecourt? ${ }^{1}$

It cannot be denied that some fundamental differences of opinion existed between Buridan and Autrecourt. As the central topic of this paper I have selected their difference of opinion on induction and causality because it re-

* Research for this paper was made possible by financial support from the Netherlands Organization for Pure Scientific Research.

1 E. A. Moody, 'Ockham, Buridan and Nicholas of Autrecourt,' Studies in Medieval Philosophy, Science, and Logic (Berkeley 1975) 127-61, options for Autrecourt. R. Paqué, Das Pariser Nominalistenstatut (Berlin 1970) and, more recently, F. Bottin, La scienza degli Occamisti (Rimini 1982) 36 are of the opinion that the statute was directed against Ockham. T. K. Scott, 'Nicholas of Autrecourt, Buridan and Ockhamism,' Journal of the History of Philosophy 9 (1971) 15-43 is of the opinion that 'neither Nicholas nor Buridan should be regarded as an Ockhamist in his theory of knowledge.' He does not discuss the statute. With the publications of Courtenay and Tachau this controversy now seems to have come to an end. Cf. W. J. Courtenay-K. H. Tachau, 'Ockham, Ockhamists, and the English-German Nation at Paris, 1339-1341,' History of Universities 2 (1982) 53-96; and W. J. Courtenay, 'The Reception of Ockham's Thought at the University of Paris,' in Preuve et raison a l'Université de Paris (edd. Z. Kałuża \& P. Vignaux; Paris 1984) 43-64. These authors have situated the 1340 statute among a number of other statutes, all of which have to do with the maintainance of discipline at the university. This statute is not concerned with specific philosophical positions, but with styles of reasoning, and it is difficult to argue that the practices proscribed in the body of the document are in accordance with those of Ockham. In addition, the external evidence associating the 1340 statute with Ockhamism is very flimsy. The rubric 'Statutum facultatis de reprobatione quorundam errorum Ockhanicorum' is an interpolation. The references in the Procurator's Book of the English-German nation and in an oath formula of 1341 were proved to be references to quite another statute which is lost. This lost statute, promulgated in January-February 1341, contained prohibitions against the 'scientia Okamica.' Without going further into this question, it suffices to say that it was directed against a group of members at the English Nation and was related to issues such as Ockham's views on universals, his reinterpretation of the categories, and the effects on the understanding of physics. It had nothing to do with Ockham's theological opinions. 
veals something about their concept of science, that is, about the possibility of achieving certain knowledge of reality. First, their views on causality will be discussed, then those on induction.

Some aspects of our subject have been treated by Anneliese Maier. Against her opinion I will argue that the differences between Buridan and Autrecourt lie not so much in the degree of certainty which has to be attached to inductive knowledge, but rather in the more fundamental problem of causality. It is precisely because of their different views on the relation between cause and effect that Autrecourt and Buridan appraise inductive knowledge differently. ${ }^{2}$ Induction is only possible if a more or less regular behavior of natural agents is assumed. By elucidating Buridan's views on causality, we may provide the broader context of his treatment of induction.

In addition, I want to make it clear that it is very unlikely that Buridan was carrying on a controversy with Autrecourt. In most treatments of the relation between Buridan and Autrecourt - whether in connection with the 1340 statute or not - it is taken for granted that Buridan had explicitly Autrecourt in mind when refuting a certain line of reasoning. ${ }^{3}$ Although the same line of reasoning does occur in Autrecourt and plays a central role in his doctrine, I nevertheless think that Buridan was not referring to it. The way Buridan reproduces this argumentation seems to exclude this possibility. ${ }^{4}$

Finally, I may make a small contribution to the solution of some problems which remained unsolved in an article by Scott. ${ }^{5}$

\footnotetext{
2 According to Maier's interpretation, Autrecourt was the one who banned the experientia from the realm of evident knowledge. But due to the intervention of Buridan, induction was rehabilitated. Cf. A. Maier, Metaphysische Hintergründe der spätscholastischen Naturphilosophie (Rome 1955) 387-88, 392-93 and 'Das Problem der Evidenz in der Philosophie des 14. Jahrhunderts,' in her Ausgehendes Mittelalter II (Rome 1967) 391-93.

3 This opinion can be found in Bottin, La scienza 123, 135; Maier, 'Das Problem' 391; Moody, 'Ockham, Buridan ...' 149-50; Scott, 'Nicholas' 31; E. Serene, 'Demonstrative Science,' in The Cambridge History of Later Medieval Philosophy (edd. N. Kretzmann, A. Kenny, J. Pinborg; Cambridge 1982) 515.

4 Bottin, Moody, and Scott all have concentrated on Buridan's theory of knowledge of substances and have taken this theory to be a refutation of Autrecourt's views. I am far from denying that there exists a difference of opinion on this subject between the two authors, but I doubt whether this established divergence of itself is sufficient reason to conclude that Buridan was carrying on a controversy precisely with Autrecourt. In contradistinction to the authors mentioned above, I have concentrated on the arguments which Buridan reproduces (in the same text as discussed by the authors mentioned above) of his opponens (whoever that may be) before refuting them. To my mind they do not correspond with those of Autrecourt. It should be noted that the chronology of the works of Autrecourt and Buridan is of no help here.

5 Scott, 'Nicholas' 37 remarks that he ignored the problem of knowledge of causal generalizations by induction: 'the main reason for this was simply that I have not been able to get clear just what Buridan's position is regarding such knowledge.' By the way, Scott seems not to have used the studies of Maier.
} 


\section{Causality}

Basic to the teaching of Nicholas of Autrecourt is the opinion that all evident knowledge must be reducible to the primum principium, the principle of noncontradiction. An inference yields evident knowledge only when the affirmation of its antecedens and the negation of its consequens are contradictory. This means that the antecedent and the consequent - or, still better, what is signified by the antecedent and the consequent - must be identical, 'because if this were not the case, it would not be immediately evident that the antecedent and the opposite of the consequent cannot stand together without contradiction.' ${ }^{\prime}$ It is within the context of this theory of evident knowledge that Autrecourt launched his attack on causality, that is, on the relations which are supposed to exist between causes and their effects. The fundamentals of his critique were well analysed by J. R. Weinberg. ${ }^{7}$

Autrecourt maintained that there are no logical reasons that posit an evident relation between a cause and an effect. Thus, the inference 'Ignis est approximatus stuppe, et non est impedimentum; ergo calor erit' is not evident. Because the antecedent and the consequent are distinct, it is not contradictory to state that there is no heat. However, if we interpret the proposition in a way in which the antecedent and consequent are identical, the argument is merely verbal, because the antecedent is interpreted in such a way that it implies the consequent. ${ }^{8}$

The above argument is taken from Autrecourt's second Letter to Bernard of Arezzo. The same line of reasoning may be found in his Letter to Aegidius. In connection with Aegidius' remark that natural agents, under proper circumstances, cause the existence of their effects, Autrecourt replies :

(A) Dico hic, quod, si per agentia naturalia intelligatis: 'Ista agentia, que sunt approximata passivis et non impedita sunt, ponunt suas actiones esse,' dicendo quod optime sequitur: Agens naturale est approximatum passivo et non est impedimentum, ergo est actio. Sed dico, quod non est evidens evidentia descripta alicui, quod in rerum universitate sint talia agentia, ymo nec quod sint ponibilia. Nam demonstratis omnibus, que sunt requisita ad effectus, potero sustinere sine aliqua contradictione, que posset inferri contra me, quod effectus huiusmodi non erit.

6 This is the text of the fifth corollary in Nicholas' second Letter to Bernard of Arezzo. For the Latin text cf. J. Lappe, Nicolaus von Autrecourt: Sein Leben, seine Philosophie, seine Schriften (Munich 1908) 8.29-34.

7 J.R. Weinberg, Nicholas of Autrecourt (New York 1969), who (18-19) translates the passage cited in n. 6 .

8 For the Latin text see Lappe, 11.29-12.11. For example, when the antecedent is interpreted to mean 'fire is productive of heat if it is near a combustible substance and there is no impediment, and it is next to the flax which is combustible and there is no impediment.' Cf. Weinberg, Nicholas 34-35. 
(B) Item, in concursu causarum potero rationabiliter credere vel dubitare saltem, utrum ibi sit aliquod agens, cuius actio sit necessario requisita ad positionem talis effectus, et per consequens non debeo credere, quod omnibus istis rebus positis necessario effectus debeat ésse necessitate tali, quod sit contradictio alio modo se habere, ut ex premissis satis patet. ${ }^{9}$

In the first part of the argumentation (A) the point is that the inference from cause to effect is either tautological or not. If tautological, we have no indication that there is really something like a causal connection. If not, the antecedent (which expresses the cause) and the consequent (which expresses the effect) are distinct and it is not contradictory to assert that the cause exists and the effect does not. ${ }^{10}$

I want to stress - perhaps superfluously - that Autrecourt with this last claim is not pointing at the so-called contingency of the effects. It was a common doctrine in the thirteenth and fourteenth centuries that agentia naturalia operate with necessity, but that their effects may be prevented. With such agents it is not contradictory to say that the cause exists and the effect does not because the latter might have been impeded per accidens by some other cause or because God has miraculously intervened in nature. ${ }^{11}$ Christian theology required the belief in several kinds of divine intervention, that is, in several exceptions to the Aristotelian explanation of nature. The best-known examples of such supernatural events were the existence of the accidents of bread and wine without their proper subject in the Sacrament of the Eucharist; the angel of Tobias who took temporarily the form of a human being (rendering it impossible to prove from effects like eating, drinking, etc., that the formal cause of that body is the human soul); and, finally, the three children who were comitted to the flames by king Nebuchadnezzar, but not burned, due to the miraculous intervention of God. ${ }^{12}$ In all these cases the effect had been impeded by divine intervention.

Autrecourt's claim, however, is much stronger, because he explicitly excludes such an impediment ('non est impedimentum'), and declares that the effect may, nevertheless, not exist. We cannot achieve logical certitude about the existence of necessary relations between cause and effect, because, as we have seen, knowledge of one thing (cause/effect) is never sufficient for evident knowledge of another thing (effect/cause).

\footnotetext{
9 Cf. Lappe, 29.1-18. A literal translation of this passage may be found in Weinberg, Nicholas 48-49.

10 Cf. Weinberg, Nicholas 48-49.

11 A. Maier, Die Vorläufer Galileis im 14. Jahrhundert (Rome 1949) 222-23.

12 Cf. Weinberg, Nicholas 90 , where some other examples are provided. The other examples are borrowed from L. Baudry, Lexique philosophique de Guillaume d'Ockham (Paris 1958) 41 (Ockham) and from F. Oakley, 'Pierre d'Ailly and the Absolute Power of God,' reprinted in his Natural Law, Conciliarism, and Consent in the Late Middle Ages (London 1984) 65 (Pierre d'Ailly).
} 
Autrecourt's argumentation here revolves around discursive knowledge of distinct things. In this respect his point is new. I do not agree with Weinberg when he declares that 'this point was anticipated by Ockham.' 13 The argument which is found in Ockham's Commentary on the Sentences, Book I prologue q. 9, concerns prediscursive knowledge:

〈Notitia incomplexa unius rei non causat notitiam incomplexam alterius rei $\rangle$. Primum declaratur per experientiam, quia quilibet experitur in se quod quantumcumque cognoscat intuitive et perfecte aliquam rem, nunquam per hoc cognoscit aliam rem nisi praehabeat notitiam illius alterius rei.

His point is that intuitive and perfect knowledge of a thing never suffices for the knowledge of another thing, unless one has previous knowledge of that other thing. Applied to the knowledge of a cause this means:

cognoscere causam sub ratione causae praesupponit notitiam illius rei quae est effectus. ${ }^{14}$

Ockham's point may be expressed — somewhat anachronistically — as follows: the assignment of an event to a cause is a 'theory-laden' undertaking. ${ }^{15}$ It presupposes knowledge of the effect which, in our conceptual framework, is connected with that cause. By designating a certain something as a cause, one has already structured reality, because one cannot speak of cause, unless one has - at least tacitly - some notion of the effect. In other words, experience of causal relations is a condition of knowing a thing sub ratione causae. It is precisely in connection with this point that induction plays a role in this dispute. I will return to this aspect a little later.

The second part of the argumentation (B) in Autrecourt's Letter to Aegidius must be seen against the background of the doctrine that God may be the sole cause of any effect. The epistemological significance of this hypothesis is that inferences that are not evident in the first place (such as the existence of secondary effects from secondary causes) do not become evident through additional qualifications, such as: God did not supernaturally produce any effects, but nature took its common course. It is a line of reasoning which Autrecourt had elaborated in his first Letter to Bernard of Arezzo:

Nam quando aliquis non est certus de aliquo consequente nisi mediante aliquo antecedente, de quo an ita sit, sicut significat, non est certus evidenter, quia nec illud est notum ex terminis nec experientia, nec ex talibus deductis, sed tantum est creditum: talis non est evidenter certus de consequente. ${ }^{16}$

13 J. R. Weinberg, Ockham, Descartes and Hume (Madison, Wisc. 1977) 55 n. 6.

14 William Ockham, Sententiae I Prologus q. 9 (Opera theologica I [edd. G. G. Gal \& S. Brown; St. Bonaventure 1967] 241.1-4, 242.3-4, 243.18-244.3.

15 Cf. N. R. Hanson, Observation and Explanation (London 1971) 28-39.

16 Lappe, 3.28-33. 
The qualification as to whether the referent of the conclusion was naturally or supernaturally produced does not alter the certainty of the conclusion. Our knowledge remains the same and, as Autrecourt had already established, we possess no evident knowledge of causal relations. Moreover, it is impossible to know when the qualification should be made, that is, when we should suppose that God has miraculously intervened or that nature has followed its communis cursus. ${ }^{17}$

John Buridan elaborated his views on causality in his commentary on the Physics, Book I q. 4: 'Utrum in omni scientia ex preexistenti cognitione principiorum, causarum et elementorum contingit alia scire, scilicet principiata, causata et elementata?'18 The title already shows that this question will say a great deal about causality. The question refers to the well-known teaching of Aristotle that we have scientific knowledge of an object only if we know the principles, causes, and elements of that object (Phys. 184a1-16). It is precisely within the context of this question that Buridan tries to give a reply to what has been regarded as the argument of Autrecourt. Buridan restates this argument in the arguments quod non, that is, in the objections to his own position:

Item revertor ad arguendum quod non posset fieri notum unum ex alio, quia de uno ad aliud non est consequentia evidens, propter hoc quod consequentia non est evidens nisi secundum reductionem ad primum principium, quia primum principium fundatur in contradictione, et contradictio debet esse eiusdem de eodem et secundum rem et secundum nomen; unde si $a$ et $b$ sunt alia $a b$ invicem, nunquam esset contradictio $a$ esse et $b$ non esse. Igitur non est evidens consequentia dicere ' $a$ est, ergo $b$ est,' et sic de quibuscumque aliis quantumque propinquam habentibus habitudinem ad invicem. ${ }^{19}$

Although a similarity with Autrecourt's line of reasoning cannot be denied, I hope to show, in my analysis of Buridan's reply, that it is very unlikely that he had Autrecourt in mind. ${ }^{20}$

17 Cf. Weinberg, Nicholas 36-37, 49-50, and 91-92.

18 Johannes Buridanus, Kommentar zur Aristotelischen Physik (Paris 1509; repr. Frankfurt 1964) (hereafter cited as In Phys.) I q. 4 (fol. $4^{\text {va }}$ ).

18 In Phys. I q. 4 (fols. $4^{\mathrm{vb}}-5^{\mathrm{ra}}$ ). This passage has been translated by Moody, 'Ockham, Buridan' 150.

20 This line of reasoning against the necessity of causal efficacy also occurs in the Arabic tradition. Cf. Averroes' 'Destructio Destructionum Philosophiae Algazelis' in the Latin Version of Calo Calonymos (ed. with an Introduction by B. H. Zedler; Milwaukee, Wisc. 1961) 403-405: 'Ait Algazel. Copulatio autem inter id quod reputatur ad modum causae, et id quod reputatur causatum, non est necessaria apud nos. Sed omnia duo, quorum hoc non est illud, nec illud hoc, et affirmatio unius non includit affirmationem alterius, nec negatio unius includit negationem alterius, non est ex necessitate esse unius esse alterius, nec ex necessitate privationis unius ut privetur alterum.' This work (in Arabic: Tahāfut al-Tahāfut) is meant to be a refutation of Algazel's Tahāfut al-Falāsifa. Averroës' procedure is to cite passages from Algazel's Tahāfut and then to state his arguments for or against his position. It is from one 
Buridan starts his determinatio by observing that his quaestio implies two further questions: (1) May we infer knowledge of one thing from knowledge of another thing? (2) What kind of things are causes or principles and what kind are effects?

Phys. I q. 4 fol. $5^{\text {ra }}$ : (A) Ista quaestio et rationes ad eam adducta implicant in se plures difficultates. Una difficultas est utrum ex notitia unius potest fieri notitia alterius .... (fol. $6^{\text {ra }}$ ) (B) Alia difficultas, scilicet cum dicimus ex causis vel principiis scire principiata et causata, quae res sint illae causae vel illa principia, et quae res sint etiam illa principiata vel causata. ${ }^{21}$

In connection with the first question (A) Buridan sets out to refute the claim that all knowledge should be reducible to the principle of non-contradiction - that is, to the only principle which is, according to Autrecourt, permitted in science. Buridan first tries to refute this claim for incomplex knowledge, that is, knowledge on a prediscursive level. The discussion is restricted to the knowledge of substances. Without going into too much detail, it is clear that Buridan's account of the question does not match the way Autrecourt had posed it. Buridan describes the problem as follows. Some people assert that no incomplex knowledge may be obtained from other incomplex knowledge, unless by way of inference. But an inference is solely from complex knowledge to complex knowledge, that is, from propositions to other propositions. ${ }^{22}$ As a corollary these people infer:

Quod nullam substantiam cognoscimus notitia incomplexa, quia non venimus in notitia substantiarum nisi per notitiam accidentium; igitur in virtute alicuius consequentiae, quae non est nisi complexorum. ${ }^{23}$

The 'quidam' of Buridan seem to have held the position that we have no intuitive knowledge of substances because knowledge of substances is discursive. This, however, is not the position defended by Autrecourt. In the first place, Autrecourt denied explicitly that we have an intuitive cognition of substances. Furthermore, he also denied that we have discursive knowledge of substances, 'quia ex una re non potest inferri quod alia res sit.' We are not allowed to make a 'jump' from the existence of the accidents (which we per-

such citation that our passage was taken. The text cited here is from a Renaissance version. The earliest translation into Latin dates from 1328 (by Calonymos I). A Latin edition of Alagazel's Tahāfut is not available, but there exists an English translation by A. Kamali, AlGhazali: Tahafut al-Falasifah (Lahore 1958) 185-86. - A similar line of reasoning may also be found in Ockham. Cf. above.

21 Cf. In Phys. I q. 4 (fol. $5^{\text {ra }}$ ).

${ }^{22}$ In Phys. I q. 4 (fol. $5^{\mathrm{ra}}$ ): 'Quaedam de incomplexa dicunt quod nulla notitia incomplexa fit per aliam, nisi virtute consequentiae. Sed consequentia non est nisi complexi ad complexum; igitur' etc.

${ }^{23}$ In Phys. I q. 4 (fol. $\left.5^{\text {ra }}\right)$. 
ceive) to the existence of the substance. ${ }^{24}$ This is a first indication that Buridan might not have had Autrecourt in mind when writing this quaestio.

Having treated incomplex knowledge, Buridan then proceeds to complex knowledge:

His autem visis de conceptibus incomplexis, aliqui etiam de complexis opinantur quod non est possibile scire hoc esse per illud esse, si hoc et illud sint alia ab invicem..$^{25}$

He reproduces two arguments of his anonymous opponents. The first objection is that only a conclusion which is reducible to the primum principium is evident. But it is not possible to find a middle term in a syllogism where the existence of $a$ is inferred from the existence of $b$. If one takes the proposition ' $a$ is $b$ ' as a middle, the existence of $a$ has already been assumed and the question begged. ${ }^{26}$

In the second objection which Buridan reproduces, it is argued that in a syllogism one should use all the premisses. But the proposition ' $a$ is $b$ ' could in this way never become a premiss in a demonstration for the existence of $a$, because the conclusion ' $a$ is' is immediately inferred from ' $a$ is $b$,' without the help of the other premiss. ${ }^{27}$

Basically the problem is that the proposition ' $a$ is $b$ ' is a necessary premiss for any inference which should be reducible to the principle of non-contradiction. For in this premiss the identity of the antecedent $(b)$ and the conclusion $(a)$ is stated. Both arguments, however, try to show that ' $a$ is $b$ ' is unsuited to function as premiss in a logical inference of the existence of $a$ from the existence of $b$. In this way, Buridan's opponents have succeeded in proving their point that such inferences are invalid. Their reasoning is thus quite different from the position taken by Autrecourt.

I now turn to Buridan's reply. His first conclusion seeks to make clear the way in which the proposition ' $a$ is $b$ ' may function in a syllogism. It is of no

24 Lappe, 11.25-12. Cf. Weinberg, Nicholas 38-40 for an exposition of Autrecourt's views.

25 In Phys. I q. 4 (fol. $5^{\mathrm{va}}$ ).

26 In Phys. I q. 4 (fol. $5^{\text {va }}$ ): '... et quia videtur eis quod impossibile sit demonstrare aliquam conclusionem in qua affirmatur de aliquo subiecto hoc verbum "est" secundum adiacens, quia non potest inveniri medium quod esset notius de illo subiecto quam hoc verbum "est." Unde statim videtur quod in sillogismo esset petitio principii, verbi gratia volo demonstrare quod $a$ est et sillogismo sic: " $b$ est" et " $a$ est $b$ "; igitur " $a$ est." Constat quod in minori propositione ego iam accipio quod $a$ est. Non enim possum scire quod $a$ est $b$, nisi prius vel simul sciam quod a est.'

${ }^{27}$ In Phys. I q. 4 (fol. $5^{\text {va }): ~ ' I t e m, ~ i n ~ s i l l o g i s m o ~ d e m o n s t r a t i v o ~ n e c ~ a d ~ m a i o r e m ~ s i n e ~ m i n o r e, ~}$ nec ad minorem sine maiore debet sequi conclusio gratia formae, quia superflueret alia premissa. Sed ad istam " $a$ est $b$ " sequitur quod $a$ est; igitur illa propositio " $a$ est $b$ " non potest esse premissa ad sillogisandum demonstrative quod $a$ est.' 
interest to us here. The other three conclusions are more promising in connection with the conflicting positions on causality and induction which we are considering. Buridan's general procedure here is to undermine the basic assumption of his anonymous opponents that there is but one principle in science, that it is only from the primum principium, that certain knowledge may be inferred. As we have seen, this is also the position defended by Autrecourt.

I illustrate Buridan's procedure with a few examples. In one conclusion he maintains that we have demonstrative knowledge of conclusions which are not reduced to the first principle. If we see a man, we know that he has a heart. The antecedent is clear from sense-perception; the consequent is certain when we have demonstrated that man cannot live without a heart..8 In this way we have inferred knowledge of the existence of $b$ from knowledge of the existence of $a$.

In a rather amusing anecdote in his commentary on the Metaphysics, Buridan even casts doubt upon the certainty of the first principle. He asked some old women whether they could be sitting and not-sitting at the same time. They said, of course, that they could not. He then pointed out to them that God is almighty and asked whether they believed that God could make them sit and not sit at the same time. They answered: We do not know. ${ }^{29}$

But the key passage for our problem is Buridan's second conclusion in question 4 in his commentary on the first book of the Physics. This conclusion provides a preamble to his views on induction. His argument is that we know many premisses of science without having reduced them to the first principle. Knowledge of these premisses of a demonstration is attained by sense-perception, memory, or experience. ${ }^{30}$

${ }^{28}$ In Phys. I q. 4 (fol. $6^{\text {ra }): ~ ' Q u a r t a ~ c o n c l u s i o ~ e s t ~ q u o d ~ i n ~ q u i b u s d a m ~ p e r ~ i s t a m ~ p r o p o s i t i o-~}$ nem " $a$ est" non solitarie sed cum alia premissa ego possum demonstrative scire istam conclusionem " $b$ est," licet $a$ sit aliud quam $b$, et $b$ aliud quam $a$. Verbi gratia, non est tibi notum ad sensum quod cor est, sed tibi est notum ad sensum quod homo est; igitur tu argues sic: "Si homo est, cor est; sed homo est; igitur cor est." Minor patet ad sensum, et maior erit nota quando demonstratum erit quod non potest homo vivere sine corde.' Cf. also Maier, Metaphysische Hintergründe 394 for a transcription.

${ }^{29}$ Johannes Buridanus, Kommentar zu Aristotelischen Metaphysik (Paris 1518; repr. Frankfurt 1964) (hereafter cited as In Metaph.) II q. 2 (fol. $9^{\mathrm{vb}}$ ): 'Unde quamvis nullus mente sanus negaret primum principium, tamen potest de eo habere formidinem. Hoc enim expertus fui. Petivi enim a pluribus vetulis, utrum scilicet crederent quod simul possent sedere et nonsedere; statim dicebant quod erat impossibile. Et tunc petivi ab eis: "Nonne creditis quod Deus posset hoc facere?" Statim responderunt: "Nescimus, Deus posset omnia facere, et quod impossibilia Deum posse facere credendum est."' Cf. also Maier, 'Das Problem' 392 n. 48 for a transcription.

${ }^{30}$ In Phys. I q. 4 (fol. $5^{\mathrm{vb}}$ ): 'Secunda conclusio contra illos est, quod non oportet omnem praemissam demonstrationis fieri notam et evidentem per reductionem ad primam principium. Multa enim principia demonstrationum fiunt nota nobis per sensum vel per memoriam vel per experientiam, absque hoc quod oporteat ea aliter demonstrari, sicut habetur secundo Posteriorum.' 


\section{INDUCTION}

This last remark of Buridan's refers to the way we may attain knowledge of the indemonstrable principles which are proper to a specific science. According to the Aristotelian notion of science, such principles serve as premisses in a

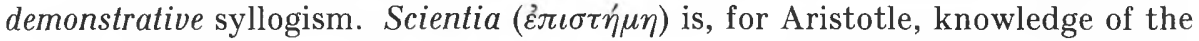
demonstrated conclusions; knowledge of the principles is referred to as intellectus (vov $\varsigma$ ). The problem is: In what way do we attain knowledge of the first principles? They cannot be demonstrated, for this would imply an infinite regression. At the same time, Aristotle wanted to avoid the assumption of a number of so-called basic truths which are not demonstrated, for this would lead to dogmatism. ${ }^{31}$

In Posterior Analytics II 19 Aristotle dealt with this problem at some length. He explicitly denied that knowledge of the first principles is innate. It must be obtained by man. Modern interpretations differ as to the way in which this knowledge is achieved according to Aristotle. His remarks seem to point to a process of intuitive induction. ${ }^{32}$ The medieval commentators on Aristotle were much clearer on this point than Aristotle himself. Buridan deals with the problem in his commentary on the Metaphysics, Book II quaestio 2: 'Utrum principia sint nobis habita naturaliter.' Through sense-experience we recognize the principle 'This fire is warm.' This sense-perception is stored in memory, and through repeated recollections of such perceptions we judge that even the fire we have not sensed is warm. This last judgement is founded on experience. ${ }^{33}$ For 'experientia est ex multis memoriis consimilium prius sensatorum iudicare de alio simili occurente. ${ }^{34}$

31 An outline of Aristotle's theory of demonstrative science may be found in J. Barnes, 'Aristotle's Theory of Demonstration,' Phronesis 14 (1969) 123-54 and in S. P. Marrone, William of Auvergne and Robert Grosseteste: New Ideas of Truth in the Early Thirteenth Century (Princeton 1983) 20-23, 251-56. The assimilation of the Posterior Analytics is treated in the survey-articles of B. G. Dod, 'Aristoteles Latinus,' in The Cambridge History of Later Medieval Philosophy (edd. N. Kretzmann, A. Kenny, J. Pinborg; Cambridge 1982) 45-80 and C. H. Lohr, 'The Medieval Interpretation of Aristotle,' op. cit. 80-99.

${ }^{32}$ Cf. Aristotle's Posterior Analytics (translated with notes by J. Barnes; Oxford 1975) 248-60 for the status quaestionis and for an interpretation of Ch. 19. See also W. Hess, 'Erfahrung und Intuition bei Aristoteles,' Phronesis 15 (1970) 48-83 for an account of the role of induction in Aristotle's works.

33 In Metaph. II q. 2 (fol. $9^{\text {va-b }}$ ): 'Et ideo sciendum est, sicut determinat Aristoteles in fine Posteriorum, quod aliqua sunt principia indemonstrabilia accepta per sensum, ut quod iste ignis est calidus. Alia autem accepta per memoriam, ut quod ignis quam heri tetigi fuit calidus. Et aliqua sunt accepta per experimentum, ut quod iste ignis quam scilicet ego $<$ non $>$ (ed. nunc) tango est calidus.' This passage has also been transcribed in Maier, Metaphysische Hintergründe 388-89.

34 This definition may be found in In Metaph. I q. 8 (fol. $7^{\mathrm{va}}$ ). It is illustrated by the same 
But this process still concerns singular principles like the knowledge that this fire is warm. Buridan must explain how the 'jump' to a universal principle is made. In order to explain the way in which we arrive at knowledge of first principles like 'All fire is warm,' or 'Rhubarb cures cholera,' he posits the natural inclination of our intellect to truth (inclinatio naturalis ad veritatem). On encountering such a universal principle, the intellect assents to it - although at times only after long deliberation - because of our natural inclination to truth. ${ }^{35}$

Buridan concludes that this process of gathering experience is nothing other than the method of induction:

Experientia ex multis sensationibus et memoriis deducta non est aliud quam inductio in multis singularibus, per quam intellectus, non videns instantiam nec rationem instandi, cogitur, ex eius naturali inclinatione ad veritatem, concedere propositionem universalem. ${ }^{36}$

These remarks about knowledge of first principles are scattered over a number of questions. Buridan expounds his ideas systematically in his Quaestiones on the Posterior Analytics, but his exposition does not deviate from the position sketched in the passage I have quoted. I may perhaps refer to one passage which provides some additional information. In Book II, question 11 of his commentary on the Posteriora Buridan stresses that knowledge of the principles is not discursive. Although the intellect uses the method of induction, this method is not in itself sufficient. It is by its own power that the intellect apprehends the first principles, precisely because it is naturally inclined to them. ${ }^{37}$

It was very common in the thirteenth and fourteenth centuries to explain knowledge of the first principles of science by a non-discursive, mental process of induction. We find an account of this process not only in the commentaries

example as was discussed above. The definition is Aristotelian (Metaph. 980a27-981a16; Anal. Post. 100a4-9).

${ }^{35}$ In Metaph. II q. 2 (fol. $9^{\mathrm{vb}}$ ): 'Postea etiam sunt aliqua principia universalia, que propter experimenta in multis singularibus consimilibus concedunt ab intellectu propter naturalem inclinationem intellectus ad veritatem...' Cf. also In Metaph. I q. 8 (fol. $7^{\mathrm{va}}$ ): 'ergo per suam inclinationem naturalem ad veritatem consurgit ad consentiendum universali propositioni.'

36 In Phys. I q. 15 (fol. 19 ${ }^{\text {ra }}$ ). Transcription also in Maier, 'Das Problem' 393.

37 A copy of Buridan's Quaestiones on the Posterior Analytics was discovered by Prof. H. Hubien (Liège). I am very grateful that he put his transcription of this text at my disposal. The question which is particularly relevant with regards to our subject is Book II q. 11 ('Utrum notitia primorum principiorum sit nobis innata'). From this question I quote the following passage: 'Ideo principiorum indemonstrabilium non est scientia proprie, sed eorum est habitus qui vocatur "intellectus," non quia sit ipsamet potentia intellectualis, sed pro tanto quia non virtute aliorum intellectorum assentit eis, sed virtute propria tanquam est naturaliter determinatus .... Et ideo, licet intellectus indigeat inductione, tamen illa non est sufficiens ad determinandum intellectum, nisi intellectus per suum naturam esset ad hoc inclinatus et determinatus' (transcription of Prof. Hubien). 
on the Posteriora by Robert Grosseteste ${ }^{38}$ and Thomas Aquinas, ${ }^{39}$ but also in the theological works of Duns Scotus and William Ockham. ${ }^{40}$

It is interesting to observe that Scotus, Ockham, and Buridan seek to validate the method of induction. As we have already seen, for Buridan the ultimate ground for justifying the truth of the inductively known principle was an 'inclinatio naturalis ad veritatem.' This becomes also very clear from a passage from his commentary on the Metaphysics (Book II q. 1). In one of the arguments quod non it is argued that inductively known principles are false,

quia experientiae ad concludendum universale principium non habent vim, nisi per modum inductionis in multis, et nunquam ex inductione sequitur universalis propositio, nisi sit inductum in omnibus singularibus illius universalis, quod est impossibile.

Buridan meets this argument with a reference to the intellect's natural inclination to truth:

Ad aliam, quae dicit quod experientiae non valent ad concludendum principium universale, dico quod non est illatio gratia formae, sed intellectus per naturalem inclinationem suam ad verum, praedispositus per experientias, assentit universali principio. ${ }^{41}$

Scotus and Ockham appeal to a special principle to establish the truth of an inductive generalization. Scotus describes this principle as a self-evident proposition in the soul to the effect that 'Quicquid evenit ut in pluribus ab aliqua causa non libera est effectus naturalis illius causae.' If in many cases an effect of a certain kind $b$ follows upon a natural cause of a certain kind $a$, we may conclude that all $a$ 's can produce $b$ 's. Ockham assumed the following principle 'Causae eiusdem generis sunt effectivae effectuum eiusdem generis vel eiusdem rationis,' or, in other words, 'Like causes have like effects.' As soon as we are certain that a particular cause $a$ is responsible for the production of the effect $b$, we may conclude - by way of the above-mentioned principle - that all $a$ 's

${ }^{38}$ Cf. Marrone 251-87 for a lucid exposition of Grosseteste's theory. J. R. Weinberg, $A b$ straction, Relation and Induction (Madison-Milwaukee 1965) 133-36 has drawn attention to the influence of the Arabic views on induction in the West. Especially Avicenna has been important in this respect. His theory came to be known via Algazel's Logic. Cf. C. H. Lohr, 'Logica Algazelis: Introduction and Critical Text,' Traditio 21 (1965) 268.334-50 and 274.553-59.

${ }^{39}$ The commentary of Thomas has been translated into English by F. R. Larcher, Thomas Aquinas: Commentary on the Posterior Analytics of Aristotle (Albany, N.Y. 1970).

40 John Duns Scotus, Ordinatio I dist. 3 pars 1 q. 4 (Opera Omnia III [Vatican 1954] 141-44); William Ockham, Sententiae I Prologus q. 2 (Opera Theologica I edd. G. G. Gal \& S. Brown [St. Bonaventure 1967] 87 and 90-96). In both cases the context is once again knowledge of the first principles.

41 In Metaph. II q. 1 (fol. $8^{\text {va }) . ~}$ 
can cause $b$. According to Ockham's account it must be certain that this particular $a$, and not some other cause, caused $b .^{42}$

Both Scotus and Ockham were of the opinion that their maxims about causality are self-evident. Scotus' theory was attacked by Autrecourt in his Exigit. Autrecourt's point is that Scotus' maxim is merely verbal. It provides a definition of a natural cause, but it is not possible to know when an agent will be a natural agent. ${ }^{43}$ The imposition of the term causa naturalis to something is an a posteriori conclusion - that is, it depends on the experience of causal routines, and it is impossible to be certain that these same routines will hold in the future. ${ }^{44}$ In other words, our experience informs us only of frequency, not of invariability.

Furthermore, Autrecourt denies that we have experience of causal relations. We only have experience of conjunction. Repetition of these experiences may provoke a conjectural habit (habitus conjecturativus), the probable expectation that in the future the same conjunction will be observed. ${ }^{45}$ Nicholas' reasoning here is consistent with his position in the second Letter to Bernard. There too he argued that we do not even have probable experience of causal nexus, because

aliquid non habet noticiam probabilem de aliquo consequente virtute alicuius antecedentis, de quo non est evidenter certus utrum consequens fuerit aliquando simul cum antecedente. ${ }^{46}$

It seems that Autrecourt does allow induction, but it is a completely different kind of induction than the other three authors have in mind. His theory of induction is based upon the observation of the repetition of event-pairs. Fur-

42 Cf. Baudry, Lexique 119-20. Weinberg, Abstraction, Relation and Induction 139-50 analyzes Scotus' and Ockham's theories on induction. According to him Scotus' theory may be compared with Mill's method of agreement, and Ockham's theory with Mill's method of difference.

43 It is the same line of reasoning we already encountered in the Letters.

44 Nicholas of Autrecourt, Exigit (ed. J. R. O'Donnell, Mediaeval Studies 1 [1939] 237 41-47): 'Cum probatur quod certitudo per propositionem quiescentem in anima quae est "illud quod producitur ut in pluribus a causa non libera est effectus ejus naturalis," quaero: Quid appellas causam naturalem? Vel illam quae produxit praeteritum ut in pluribus et adhuc producet in futurum si duret et applicetur? Et tunc minor non est scita, esto quod aliquid sit productum ut in pluribus; non est tamen certum an sic debeat esse in futurum.' This passage has been analysed in Maier, 'Das Problem' 390-91 and in Weinberg, Nicholas 69-71. More or less the same criticism holds for Ockham. Experience of the regularity of nature is needed for expressing causal routines in a universal proposition. There is, however, no guarantee that the same routines will hold in the future.

${ }_{45}$ Nicholas of Autrecourt, Exigit (237 39-41): 'Tertia decima conclusio est quod de scitis per experientiam illo modo quo dicitur sciri "rheubarbarum sanat choleram" vel "adamas attrahit ferrum," habetur solum habitus conjecturativus, non certitudo.'

46 Lappe, 13.6-8. Cf. Weinberg, Nicholas 111-12. 
thermore, according to Autrecourt induction provides only probable knowledge. It is only with probability that we may anticipate that the same eventpairs will repeat themselves. Scotus, Ockham, and Buridan believed that something can be learned from induction, that induction can provide an insight in the causal interconnections of phenomena.

If we now return to Buridan's views, recalling the context in which he made his statements, we observe that he does not adequately reply to his anonymous opponents. In his commentary on the Physics I, the fourth question arose out of the fact that some people recognized only one principle of science, the primum principium - a claim which rendered knowledge of causal relations impossible. Since Buridan was unable to accept this consequence, he attempted to refute his opponents by showing that the first principle is not the only principle of scientific knowledge. As we have seen, one of his arguments was that there are, as a matter of fact, many principles in science and that these principles are known by induction, that is, by sensory perception, memory, and experience. But here Buridan is begging the question, because in his account of the inductive process, he presupposes the possibility of knowledge of causal relations. It is exactly this kind of knowledge which is excluded by the claim that all evident knowledge should be reducible to the first principle. The presupposed knowledge of causal relations was his reason for attacking this claim in the first place.

A petitio principii would be, however, avoided, should it turn out that Buridan does not attach the same degree of certainty to inductively known principles as to the first principle. His answer to this question may be found in the questions on the Metaphysics, Book II q. 1 ('Utrum de rebus sit nobis possibilis comprehensio veritatis?'). There he posits a third kind of comprehensio veritatis which is relevant to this issue:

Alio modo comprehensio veritatis accipitur pro adhaesione vel assensu quo assentimus vel adhaerimus propositioni vere, et adhuc constat quod hoc est nobis possibile.

And the question is further specified:

Utrum talis assensus veritatis sit nobis possibilis cum certitudine. ${ }^{47}$

Buridan seems to maintain that the certainty of our assent is of two kinds: simpliciter and secundum quid or ex suppositione (communis cursus naturae). The first kind of evidence appears when one is necessitated to assent to a proposition, because one cannot do otherwise. An example of such a proposition is the first principle. ${ }^{48}$ The second kind of evidence is valid, only if the

\footnotetext{
47 In Metaph. II q. 1 (fol. $8^{\mathrm{vb}}$ ).

48 In Metaph. II q. 1 (fol. $8^{\text {rb }}$ ): 'Et vocatur evidentia propositionis simpliciter, quando ex natura sensus vel intellectus homo cogitur <sive necessitatur > (Ed: sine necessitate), ad
} 
miraculous intervention of God is excluded. But if we assume the common course of nature, we may confidently assent to propositions like 'All fire is warm,' and this kind of evidence is sufficient for the principles and conclusions of natural science. ${ }^{49}$ With this qualification, the possibility of certain knowledge is guaranteed:

Ideo conclusum est corollarie, quod aliqui valde mali dicunt volentes interimere scientias naturales et morales, eo quod in pluribus principiis et conclusionibus non est evidentia simplex, sed possunt falsificari per casus supernaturaliter possibiles, quia non requiritur ad tales scientias evidentia simpliciter, sed sufficiunt predictae evidentiàe secundum quid, sive ex suppositione. Ideo bene dicit Aristoteles secundum huius, quod non in omnibus scientiis mathematica acribologia est expetenda. Et quia iam apparuit quod omnibus predictis modis firmitas veritatis et firmitas assensus sunt nobis possibiles, ideo concludendum est quod querebatur, scilicet quod nobis est possibilis comprehensio veritatis cum certitudine. ${ }^{50}$

We may conclude that Buridan has avoided a petitio principii, because he only claims a conditional evidence for the principles proper to natural science, whereas evidentia simpliciter is required for the first principle. It is doubtful, however, whether Buridan was aware that he came close to begging the question, because his reason for introducing evidentia secundum quid alongside evidentia simpliciter has nothing to do with the reservations we made with regard to the validity of his argumentation.

In introducing conditional evidence, he was necessitated by the requirements of Christian theology: there had to be room for miracles. At the same time, conditional evidence was introduced to express the fact that natural effects take place ut in pluribus. That is that they take place on the assumption of the common course of nature, which may be impeded so that the effect is produced ut in paucioribus. The standard example for such effects was that men are born with ten fingers ut in pluribus, but that men have been known to have been born at times - ut in paucioribus or a casu - with eleven fingers. It was a common medieval doctrine, already implicit in Aristotle, that nature can be assumed to run its common course and that chance occurrences may be excluded, if one wishes to know something of causes and future events. ${ }^{51}$

assentiendum propositioni ita, quod non potest dissentire, et huiusmodi evidentia secundum Aristotelem conveniret primo principio complexo, ut patet quarto huius.'

${ }^{49} \mathrm{Cf}$. In Metaph. II q. 1. These passages have also been transcribed and discussed by Maier, 'Das Problem' 398-403.

$50 \mathrm{Cf}$. foregoing note.

51 For this reason I do not quite agree with the interpretation that Bottin, La scienza 135 has given of the evidentia ex suppositione: '... egli [Buridan] pero difende la dottrina occamista del possibile intervento divino nelle leggi di natura e di consiguenza costruisce una scienza puramente congetturale e ipotetica,' and (op. cit. 210-11): 'Infatti, Giovanni Buridano, benché cerchi di evitare con ogni cura le ingerenze a livello scientifico della teologia e benché 
The introduction of evidentia secundum quid or ex suppositione was based on a long tradition. It may be found in Thomas Aquinas, Duns Scotus, William Ockham, and many more medieval authors. ${ }^{52}$ As we have seen, Autrecourt drew an important methodological consequence from the theological exceptions: it is impossible to know when the supposition of the common course of nature is validly applied. ${ }^{53}$ But in the passages known to me, Buridan shows no signs of acquaintance with this line of reasoning. For this reason and because of our conclusions from Buridan's argumentation in his commentary on the Physics I q. 4, it is my conviction that Buridan did not know the doctrines of Nicholas of Autrecourt in any detail. The only resemblance I have been able to establish is that Buridan was in touch with the line of thought that evident knowledge of the existence of $b$ may not be inferred from the knowledge of the existence of $a$ if $a$ and $b$ are distinct, which also occurs in the works of Autrecourt. Buridan even considers this argument as threatening the possibility of knowledge of causal relations, but he seems to be unaware of the subtle ways Autrecourt used this basic idea in his attacks on causal knowledge.

cerchi di smorzare molte delle polemiche relative appunto alla possibilità di uno diretto intervento divino nelle cause naturali, in realta elabora egli stesso una epistemologia nella quale il "casus supernaturaliter possibilis" e continuamente preso in considerazione.' To my mind, the case of a divine intervention is too much stressed here. G. Federici-Vescovini, 'Arti' e filosofia nel secolo XIV (Florence 1983) 35-36 makes a connection between the suppositio naturalis and induction which is not altogether clear to me. Her way of presenting the problem gives the impression that 'supposizione naturale' has something to do with 'supposizione del communis cursus naturae.'

52 Cf. Maier, Die Vorläufer 219-50 (Notwendigkeit, Kontingenz und Zufall). Aquinas' position on this point is discussed in A. Van Hove, La Doctrine du miracle chez Saint Thomas et son accord avec les principes de la recherche scientifique (Wetteren-Bruges-Paris 1927), in K. Jacobi, 'Kontingente Naturgeschehnisse,' Studia mediewistyczne 18 (1977), 3-70 and in W. A. Wallace, 'Aquinas on the Temporal Relation Between Cause and Effect,' Review of Metaphysics 27 (1974) 569-84. Interesting passages of earlier medieval authors on miracles and the common course of nature are presented in B. Ward, Miracles and the Medieval Mind: Theory Record and Event 1000-1215 (London 1982) 3-33. A second objection to the exposition by Bottin, La scienza (notably on p. 214) is that he gives the impression that Buridan's remarks about the evidentia ex suppositione communis cursus naturae have something in common with the hypothetico-deductive methodology of modern science. Buridan, however, is not advocating here that one should pose hypotheses in the sense of hypothetical syllogisms or that he admitted 'an order of hypothetical necessity' as Moody, 'Ockham, Buridan' 154, has put it. For criticism of this position see W. A. Wallace, 'Buridan, Ockham, Aquinas: Science in the Middle Ages,' The Thomist 40 (1976) 481-82 and Maier, 'Das Problem' 403 n. 65 . A good survey of the different meanings of the expression ex suppositione and the Aristotelian roots of this notion is provided in W. A. Wallace, 'Aristotle and Galileo: The Use of vंó $\theta \varepsilon \sigma \iota \varsigma$ (Suppositio) in Scientific Reasoning,' in Studies in Aristotle (ed. D. J. O'Meara; Washington 1982) 47-77.

53 Cf. Weinberg, Nicholas 91-93. 
A last problem must be clarified. Why was it so important for Buridan to meet the arguments that denied the possibility of causal knowledge? The importance he attached to the problem may be seen in the fact that he devoted the whole of question 4 to this refutation. The answer is rather simple. As we have already seen, Buridan agreed with the Aristotelian notion of science. According to the Aristotelian view a thing is scientifically known when its causes are known (Anal. Post. 71b10-12):

Scire autem opinamur unumquodque simpliciter, sed non sophistico modo quod est secundum accidens, cum causam cognoscere arbitramur propter quam est res, quoniam illius est causa, et non contingere hoc aliter se habere. ${ }^{54}$

The claim of his opponents, however, that all demonstrations should be reducible to the primum principium would render such causal explanations impossible.

It was in this context that Buridan enunciated his second difficulty (B): 'Quae res sint causae vel illa principia et quae res sint etiam illa principiata vel causata?'55

His conclusions make it clear that for Buridan the principle of causality is active on two levels. On the first level, the knowledge of the premisses in any demonstration (quia or propter quid) is the cause of the knowledge of the conclusion, and this cause is an efficient cause. ${ }^{56}$ On the second level, the relation between cause and effect both in a demonstration quia and in a demonstration propter quid is founded on the res which are known. That is to say, there is a habitudo causae ad causatum on the level of things in reality. (Mathematical demonstrations are an exception to this rule. They are called propter quid, because in them inference is made from propositions which are better known to us by nature to propositions which are less known to us. $)^{57}$

54 Aristoteles Latinus, Analytica Posteriora 71b10-12 (edd. in the translation of William of Moerbeke by L. Minio-Paluello \& B. G. Dod [Bruges/Paris 1968] 268).

55 In Phys. I q. 4 (fol. $6^{\text {ra }}$ ); cf. above.

56 In Phys. I q. 4 (fol. $6^{\text {ra }}$ ): Secunda conclusio est quod in omni demonstratione - sive quia, sive propter quid - scientia praemissarum est causa scientiae conclusionis ... et secundum Linconiensem huiusmodi causalitas est in genere causae efficientis.

57 In Phys. I q. 4 (fol. $6^{\text {rb }}$ ): 'Ego credo quod communiter in demonstrationibus mathematicis non est ex parte rerum significatarum per medium et per terminos conclusionis habitudo causae ad causatum vel econversa. Sicut est aliquando in naturalibus propter quid ita est in mathematicis.... Sed tamen illas demonstrationes mathematicas solemus vocare propter quid, quamvis ex parte rerum significatarum non sit habitudo aliqua causae ad causatum. Non enim solum attendimus ad causalitatem scientiae et ad scientiam et vocamus demonstrationem propter quid quae procedit ex propositionibus naturaliter evidentibus et magis scitis ad propositiones dubitabiles et ignotas sciri per illas magis scitas, et sic est in mathematicis. Ubi autem ex parte rerum est habitudo causae ad causatum, nos aliter distinguimus demonstrationem quia et propter quid, sicut ante dictum est.' 
Thus inferences of the existence of $b$ from the existence of $a$ must be allowed,

aliter etiam perirent demonstrationes verae et propriae propter quid, cum maxime propinqua sit et essentialis habitudo causarum ad causata, eo quo causata habent esse per causas et propter suas causas. Ideo, cum dictum sit quod ex scientia unius potest nobis fieri scientia alterius, hoc maxime debet concedi, quod ex scientia causarum potest nobis fieri scientia causatorum. ${ }^{58}$

The point is that a position according to which all scientific principles must be reduced to the primum principium would lead to the destruction of science as it was conceived by Aristotle. The same thought was expressed some years later by Pierre d'Ailly:

Secundo sequitur, quod non posset sufficienter inferri ex una re alia nec ex causa posset concludi effectus nec e contra, et sic perirent omnes demonstrationes naturales. ${ }^{59}$

\section{Conclusion}

The passages of Nicholas of Autrecourt discussed here were taken, for the most part, from his Letters. As is well known, many theses taken from the Letters and from the Exigit were condemned in 1346. But Autrecourt pointed out to his judges that the doctrines proposed in the correspondence with Bernard of Arezzo were stated disputatively. He had agreed with Bernard to take the primum principium as the standard of certain knowledge and to explore where this would lead.60 It is difficult to decide whether Nicholas was sincere or this remark was merely a tactical maneuver. But neither of these possibilities affects our exposition. My purpose has been to contrast two different

58 In Phys. I q. 4 (fol. $6^{\mathrm{rb}}$ ). Buridan's conviction that a relation exists between cause and effect is also expressed further on in the same question (fol. $6^{\text {va }}$ ): 'Ubi autem esset determinatio per naturam non concurrente actu libero voluntatis, ego crederem quod semper ex causis sufficientibus positis sequeretur effectus, nisi interveniret impedimentum.'

59 Transcription in Maier, 'Das Problem' 411. The context of d'Ailly's observation is: 'quod loquendo de evidentia secundum quid seu conditionalis vel ex suppositione, scilicet stante Dei influentia generali et cursu naturae solito nulloque facto miraculo talia possunt esse nobis sufficienter evidentia, sic quod de ipsis non habemus rationabiliter dubitare.' Doubting this kind of evidence would entail many inconveniences and absurdities, the second of which has been mentioned above.

60 Lappe, Nicolaus 35.17-25: 'Reverendissimis patribus notum sit quod, quando magister Bernardus predictus et ego debuissem disputare, concordavimus ad invicem disputando conferre de primo consensu omnium principio, posito a philosopho quarto Metaphisice, quod est: "Impossibile est aliquid eidem rei inesse et non inesse," loquendo de gradu evidentie qui est in lumine naturali strictissimus. Istis suppositis dixi in predictis epistolis, eo quod tales conclusiones nec implicite continebant contradictionem nec explicite, ut tunc dicebam causa collationis. Et in hoc consistit totum motivum quod tunc habui.' 
concepts of science, one which claimed that there is but one ultimate principle of science, the primum principium, and another which claimed that there are nearly as many principles as there are conclusions.

We may, therefore, summarize the results to which these different options lead. One of the consequences of Autrecourt's point of departure is that he must abandon the possibility of knowing causal relations. Neither experience nor logic is able to provide us with this kind of knowledge. Autrecourt's strict conception of certitude entails the destruction of science in the Aristotelian sense. What remains is a science of mere tautologies, for only those inferences are evident in which antecedent and consequent are identical.

Buridan's position is Aristotelian. He leaves intact the possibility of knowing causal chains, and for this reason he is able to assert that there are many indemonstrable principles of sciences which may be known by way of induction. His assumption of the existence of causal routines is in reality an a priori assumption. But it is a necessary assumption for maintaining the possibility of induction. The very same presupposition underlies the maxims that Scotus and Ockham formulated to render inductively known principles indubitable. At the same time, it is by way of induction that causal routines are discovered, or perhaps better, that reality is structured along causal chains.

I hope to have thrown a little light on the way induction and causality were intertwined in the fourteenth-century debate. I must reject Maier's portrayal of this debate. I have tried to argue not only that a direct confrontation between Autrecourt and Buridan never took place, but also that their opinions diverged primarily because of Autrecourt's refusal to make gratuitous assumptions about causality. The standards he set for certain knowledge do not allow him to make such presuppositions. Some anonymous, or perhaps illusive, opponents of Buridan seem to have held the same standards. Buridan attacked them because he saw these standards as a threat to the relation he supposed to exist between cause and effect, and therewith to the Aristotelian concept of science. I cannot say that the option Buridan has chosen is more rational, but it is certainly more Aristotelian and perhaps (as is often the case with Aristotelian positions) more in accord with common sense. In daily life men arrange their experiences in conceptual frameworks of cause and effect. In doing so, they suppose that they are doing more than simply observing repetitions of a sequence of events. Autrecourt's option was completely different. A dialogue between their two concepts of science is not really possible.

Katholieke Universiteit

Nijmegen 